\title{
PARASITIC WASPS (HYMENOPTERA) ASSOCIATED WITH FRUITS OF ILEX AFFINIS GARDNER (AQUIFOLIACEAE) IN BRAZIL WITH DESCRIPTION OF TWO NEW CHALCIDOIDEA
}

\author{
N.W. Perioto' ${ }^{1}$, R.I.R. Lara ${ }^{1}$, V.A. Costa ${ }^{2}$ \\ ${ }^{1}$ Apta Regional Centro-Leste, Laboratório de Bioecologia e Taxonomia de Parasitóides e Predadores, Rua Peru, \\ 1472-A, CEP 14075-310, Ribeirão Preto, SP, Brasil. E-mail: nperioto@apta.sp.gov.br
}

\begin{abstract}
This paper presents a survey of parasitic Hymenoptera obtained from fruits of Ilex affinis (Aquifoliaceae) collected in area of the Brazilian savannah (cerrado) in São Paulo State, Brazil. At the site studied, three species of Chalcidoidea, Galeopsomyia itauna sp. nov. (Eulophidae),Prodecatoma juliae sp. nov., Sycophila sp. (Eurytomidae) and one non identified species of Doryctinae (Braconidae) were found associated with I. affinis fruits.
\end{abstract}

KEY WORDS: Braconidae, Brazilian savanna, Galeopsomyia, Prodecatoma, Sycophila.

\section{RESUMO}

VESPAS PARASITÓIDES (HYMENOPTERA) ASSOCIADAS A FRUTOS DE ILEX AFFINIS GARDNER(AQUIFOLIACEAE)NOBRASILCOM A DESCRIÇÃODEDUASNOVASESPÉCIESDE CHALCIDOIDEA. Este artigo apresenta os himenópteros parasitóides obtidos a partir de frutos de Ilex affinis Gardner (Aquifoliaceae) coletados em área de vegetação de cerrados no Estado deSão Paulo, Brasil. No local estudado, três espécies de Chalcidoidea, Galeopsomyia itauna sp. nov. (Eulophidae), Prodecatoma juliae sp. nov., Sycophila sp. (Eurytomidae) e uma espécie não identificada de Doryctinae (Braconidae) foram associadas a frutos de I. affinis.

PALAVRAS-CHAVE: Braconidae, cerrado, Galeopsomyia, Prodecatoma, Sycophila.

\section{INTRODUCTION}

The cosmopolitan genus Ilex (Aquifoliaceae) comprising more than 400 tropical and temperate species is distributed mainly by East Asia and South America; this genus is also well represented in South East Asia, Central America and North America and a few species occur in tropical Africa, tropical Australia, Europe, Hawaii, Tahiti, the Caribbean, the Canary Islands, the Azores, Madeira, New Caledonia and Fiji (MANEn et al., 2002).

Ilex affinis Gardner is a shrub or small tree with rough bark and glabrous branches; the leafs are oval, lanceolate, alternate and have crenated base; the fruits are, when ripened, a globose drupe, rugose, sulcated, dark purple colored with ca. of four $\mathrm{mm}$ diameter (Durigan et al., 2004). This species occurs in weeping grounds of Brazilian savanna and is included in the official roll of endangered species of São Paulo State.

Prodecatoma Ashmead, 1913 (Hymenoptera, Eurytomidae) is eminently a pan-tropical genus, with
45 species (DALMolin et al., 2004), twelve of which occur in Brazil (NoYEs, 2003). Most of your larvae have phytophagous habits and the associations described by GIRAULT (1920) of P. maga to Andricuschrysolepidicola (Ashmead), 1896 and to Disholcaspis plumbella Kinsey, 1920 (Hymenoptera, Cynipinae) are the only known association between species of Prodecatoma and non vegetal hosts and need to be confirmed. Records in literature associate this genus with, at least, nine families of plants (PERIOTO; LARA, 2004).

The genus Galeopsomyia Girault, 1916 (Hymenoptera, Eulophidae) comprises 19 species distributed by the New World, 14 of which have a Neotropical distribution and seven of them were recorded to Brazil (Noyes, 2003; РеRioto et al., 2007). All species of Galeopsomyia, except G. fausta LaSalle, 1997, a parasitoid of the citrus leafminer (CLF) Phyllocnistis citrella Stainton (Lepidoptera, Gracillariidae), are parasitoids or eventually inquilines of insects that develop in galls (LASALLE; PEÑA, 1997).

\footnotetext{
${ }^{2}$ Instituto Biológico, Centro Experimental Central, Campinas, SP, Brasil.
} 


\section{MATERIAL AND METHODS}

Green fruits of Ilex affinis were collected in a residual area of Brazilian savanna located at Fazenda Itaúna $\left(21^{\circ} 54^{\prime} 05^{\prime \prime} \mathrm{S} / 47^{\circ} 37^{\prime} 26^{\prime \prime} \mathrm{W}\right)$ in Descalvado County, São Paulo State, Brazil, and maintained in plastic containers ( $20 \mathrm{~cm}$ diameter, $25 \mathrm{~cm}$ high) covered with synthetic gauze and daily observed until putrefaction. All the wasps emerged were identified, quantified and stored in glass vials with ETOH 70\%; posteriorly they were mounted in entomological pins. Eighty eight seeds, from 50 fruits, were dissected under stereomicroscope and data of the presence of insects in its interior recorded. Observations for descriptions were made using a Leica MZ 9.5 stereomicroscope and fluorescent light source. Images of scanning electron micrographs were made with a Jeol JSM5200 SEM of the Departamento de Biologia Celular e Molecular e Bioagentes Patogênicos da Faculdade de Medicina de Ribeirão Preto/USP. The images were captured on Neopan 100 film and digitized from the negative using a scanner. The figures were prepared using Adobe@ Photoshop. The specimens of Galeopsomyia were identified at generic level by the key proposed by SCHAUFF et al. (1997) and at specific level by comparison with descriptions of the species found in the literature. Morphological terminology follows GiBson (1997) except for basigastral carina - a strong transverse carina along the anterior margin of the first gastral tergite - and basigastral costula-any longitudinal carina extending posteriorly from the basigastral carina (see LASALLE; PEÑA, 1997). Sculpturing terminology follows HARRIS (1979). Abbreviations are as follow: $\mathrm{F} n$, flagellomeres ( $n=$ number of the flagellomere); IAA, interantennal area; $\mathrm{Mt} n$, metasomal tergites $n=$ number of the metasomal tergite); OOL= ocello-ocular distance; $\mathrm{POL}=$ post-ocellar distance.

\section{List of repositories}

MZSPMuseu de Zoologia da Universidade deSão Paulo (São Paulo, Brazil). C. R. F. Brandão, curator.

UFES Universidade Federal do Espírito Santo (Vitória, Brazil). C. O. Azevedo, curator.

\section{RESULTS}

From the fruits were reared 21 specimens of Eurytomidae (Hymenoptera): 20 females of Prodecatoma juliae sp. nov. and one male of Sycophila sp., 20 females and 10 males of Galeopsomyia itaunasp. nov. (Hymenoptera, Eulophidae) and two males of a not identified species of Doryctinae (Hymenoptera, Braconidae).
In the 50 dissected seeds fruit were found 88 seeds (1.8 seed/fruit), 63 (71.6\%) infested by chacids from which $8(12.7 \%)$ were attacked by Galeopsomyia itauna sp. nov., 55 by (87.3\%) Prodecatoma juliae sp. nov. and one $(1.6 \%)$ by Sycophila sp. Records in the literature show that immature stages of Prodecatoma and Sycophila are seed infesting chalcids; probably Galeopsomyia is a infesting parasitoid of the seed and the ecological function of the Doryctinae was not established.

\section{Galeopsomyia itauna, Perioto \& Costa sp. n.}

(Figs. 1 - 11)

Diagnosis: female length $=2.0-2.6 \mathrm{~mm}$. Body strongly sclerotized; metacoxa with a strong dorsalposterior carina; gaster non-collapsing in dried specimens; basigastral carinae incomplete and a few short costulae present (difficult to see under optical microscopy); petiole very thin, difficult to see; gastral tergites reticulate dorsally; propodeum with strong paraspiracular carina, costula medially indefinite and strong transverse carina along posterior margin; malar space with a triangular fovea below eyes; fore wing with 4-7 setae on dorsal surface of submarginal vein.

Holotype female: length $=2.6 \mathrm{~mm}$. Head and mesosoma black with green-bluish metallic shine except by coloration: brown on apical portion of the clypeus, gena near mandibles, mandibles, tegula, acropleuron and ovipositor sheath; yellow on scape (dorsally infuscated), pedicel and legs (metafemur medially infuscated); light brown flagellum; dark red eye and ocelli; dark brown coxa. Gaster: basal portion of Mt1 with similar coloration of mesosoma, subsequent segments with transversal stripes of metallic coloration not as intense as Mt1, Mt7+Mt8 not metallic. Wings hyaline, setae and veins light brown. Body with white setae.

Head (Fig. 1): $1.1 \times$ wider than high; POL/OOL = 1.8; eye $2.0 \times$ the length of malar space; gena near malar space smooth, supraclypeal area coriarious, upper and lower face imbricate. Scrobal depression without distinct sulci, but with a longitudinal median ridge; face with a strong furrow interrupted medially between torulus and mouth margin; clypeus distinctly bilobed; malar space (Fig. 2) with a triangular fovea (length= ca. $0.5 \times$ malar sulcus) below eye.

Antenna (Fig. 3): scape 3.7x, pedicel $1.8 \times$, 3 anelli, F1 (2.4x), F2 (1.9x), F3 (1.4x) and clava (3 segmented) $2.5 \times$ longer than wide.

Mesosoma: $1.5 \times$ longer than wide, reticulate in dorsal view (Fig. 4) except the scutellum imbricate (Fig. 5). Mesoscutum with notauli deep, median line indistinct on anterior third and well defined on medium and posterior third; two lines of adnotaular setae adjacent to the notauli; scutellum with several 
pairs (4-6) of setae, sub median groove well defined, median line vaguely indicated; in lateral view with a set of incomplete carinae on anterior margin (Fig. 6). Dorsellum longitudinally divided by a carina. Propodeum (Fig. 7) reticulate, with strong paraspiracular carina, median carina complete, costula medially indefinite and strong transverse carina along posterior margin. Metacoxa (Fig. 8) with a strong dorsal-posterior carina. Petiole very thin, difficult to see.

Fore wing (Fig. 9): $2.2 \times$ longer than wide; submarginal vein $1.0 \times$ length of marginal vein; marginal vein $3.2 \times$ length of stigmal vein; post-marginal vein absent; submarginal vein with 5 setaeondorsal surface; setae on distal portion of the costal cell; speculum and basal cell present, not delimited by cubital setal line, basal setal line indicated by only two setae.

Metasoma(Fig. 10):2.9x longer than high inlateral view and $2.8 \times$ longer than wide in dorsal view, reticulate, $\mathrm{Mt} 2 \mathrm{in}$ dorsal and lateral view is the shorter, Mt4 in dorsal view is the longer.

Variability: body length 2.0-2.6 mm; head 1.1-1.2x wider than long; $\mathrm{POL} / \mathrm{OOL}=1.6-2.1$; eye height 1.8 2.0 $\mathrm{x}$ malar space; scape 3.0-3.8 $\mathrm{x}$, pedicel 1.8-2.3 $\mathrm{x}, \mathrm{F} 1$ (2.1-2.4x), F2 (1.9-2.0x), F3 (1.4-2.0x) and clava 2.5-3.8 $x$ longer than wide. Mesosoma 1.5-1.6 $x$ longer than widein dorsal view; mesoscutum with 7-10 adnotaular setae; the infuscation on metafemur can be more basal. Fore wing 2.2-2.6 $x$ longer than wide; submarginal vein $0.9-1.0 \times$ length of marginal vein; marginal vein 3.2-3.6x length of stigmal vein; submarginal vein with 4-7 setae on dorsal surface. Metasoma 2.5-3.5x longer than high in lateral view and 2.7-3.2 $x$ longer than wide in dorsal view.

Male alotype: length $=2.2 \mathrm{~mm}$. Similar to females except by the dark brown color of the gaster (with a dorsal pale yellow spot on Mt1 and Mt2) and sexual differences in genitalia and antenna. Antenna (Fig. 11) with 4 funicular segments. Funicular segments with basal whorls of long setae, ca. 2.6 x longer than length of correspondent segment. Scape $3.1 \mathrm{x}$, pedicel $1.8 \mathrm{x}, \mathrm{F} 1(1.4 \mathrm{x}), \mathrm{F} 2(2.9 \mathrm{x}), \mathrm{F} 3(3.0 \mathrm{x}), \mathrm{F} 4(3.4 \mathrm{x})$ and clava (3 segmented) $8.5 \times$ longer than wide, one anelli. Scape with meso-apical dark brown ventral plaque, ca. $0.4 \times$ length of scape. Mesosoma $2.1 \times$ longer than wide in dorsal view. Metasoma $2.4 \times$ longer than high in lateral view and $3.2 \times$ longer than wide in dorsal view.

Male variation: length $=1.7-2.2 \mathrm{~mm}$; head 1.1-1.3 $\mathrm{x}$ wider than long; $\mathrm{POL} / \mathrm{OOL}=1.8-1.9$; eye height $1.7-$ $1.9 \times$ malar space; scape $2.6-3.1 \mathrm{x}$, pedicel 1.7-2.0 $\mathrm{x}, \mathrm{F} 1$ (1.2-1.4x), F2 (2.4-3.0x), F3 (3.0-3.3x), F4 (3.0-3.4x) and clava 7.0-8.5 $\mathrm{x}$ longer than wide. Mesosoma 1.5-1.9x longer than wide in dorsal view. Fore wing 2.1-2.3 $x$ longer than wide; submarginal vein 1.0-1.1 x length of marginal vein; marginal vein 2.6-3.2 $x$ length of stigmal vein. Metasoma 2.6-3.2 $x$ longer than high in lateral view and 2.3-3.6 $\times$ longer than wide in dorsal view.

Distribution: Descalvado, São Paulo State, Brazil.

Remarks: Galeopsomyia itauna sp. n. share with G. fausta La Salle \& Peña, 1997 and G. viridicyanea Ashmead, 1904 the presence of the basigastral carinae; that lacks in all other species of Galeopsomyia. This species differs from G. fausta in lacking a distinctly visible petiole and of G. viridicyanea by having the metasoma lower than $2.0 \times$ the length of mesosoma and by the color of the body.

Biology: Galeopsomyia itauna sp.n. were reared from seeds of Ilex affinis (Aquifoliaceae) and probably is a parasitoid of the seed infesting Prodecatoma juliaesp.n.

Type material (19 females): Holotype female (MZSP): Brasil, São Paulo, Descalvado, Fazenda

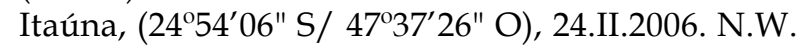
Perioto eeq. col., ex. frutos deIlex affinis (Aquifoliaceae); alotype male (MZSP): same data as holotype. Paratypes: same data as holotype; 9 females and 4 males (MZSP), 8 females and 3 males (UFES).

Etymology: The specific epithet refers to Fazenda Itaúna, near Descalvado (SP), Brazil, type locality.

\section{Prodecatoma juliae Perioto \& Lara sp. nov.} (Figs. 12 - 19)

Diagnosis: female length $2.6-2.7 \mathrm{~mm}$. Head, funicle (except clava) and mesosoma yellow (the color is little darker in scutellum, metanotum, propodeum and mesopleura);legs paleyellow; apex of mandibles, ocellus and petioledark brown, clavaand metasomalightbrown.

Female holotype: length $=2.6 \mathrm{~mm}$. head, funicle (except a brown clava), pronotum and mesonotum gold yellow; mesopleuron, scutellum, axillae and propodeum light brown; metasoma brown; apex of mandibles, ocellus, petiole dark brown; legs pale yellow; eyes reddish; wings hyaline, setae and veins (except a hyaline break in small apical portion of the submarginal vein) light yellow; body with white setae.

Head (Fig. 12): upper and lower face areolate, ventral portion of lower face with striae converging toward clypeus; margin of clypeus straight; $1.2 \mathrm{x}$ wider than high; $\mathrm{POL} / \mathrm{OOL}=1.6$; eye $1.6 \mathrm{x}$ the length of malar space; malar space glabrous (Fig. 13); malar sulcus complete, difficult to see under optical microscopy; scrobal depression smooth, laterally carenate, IAA $0.6 \times$ the length of scrobal depression.

Antenna (Fig. 14): scape $4.7 x$, pedicel $1.4 x$, one anelli, F1 (1.8x), F2 (1.6x), F3 (1.5x), F4 (1.4 x), F5 (1.3 $\mathrm{x})$ and clava (three segmented) $3.4 \mathrm{x}$ longer than wide.

Mesosoma (Figs. 15, 16): in dorsal view densely foveolate, $2.0 \times$ longer than wide, notauli complete; propodeum (Fig. 17) areolate, medially glabrous and delimited by plical carina, with transversal irregular carinae. 

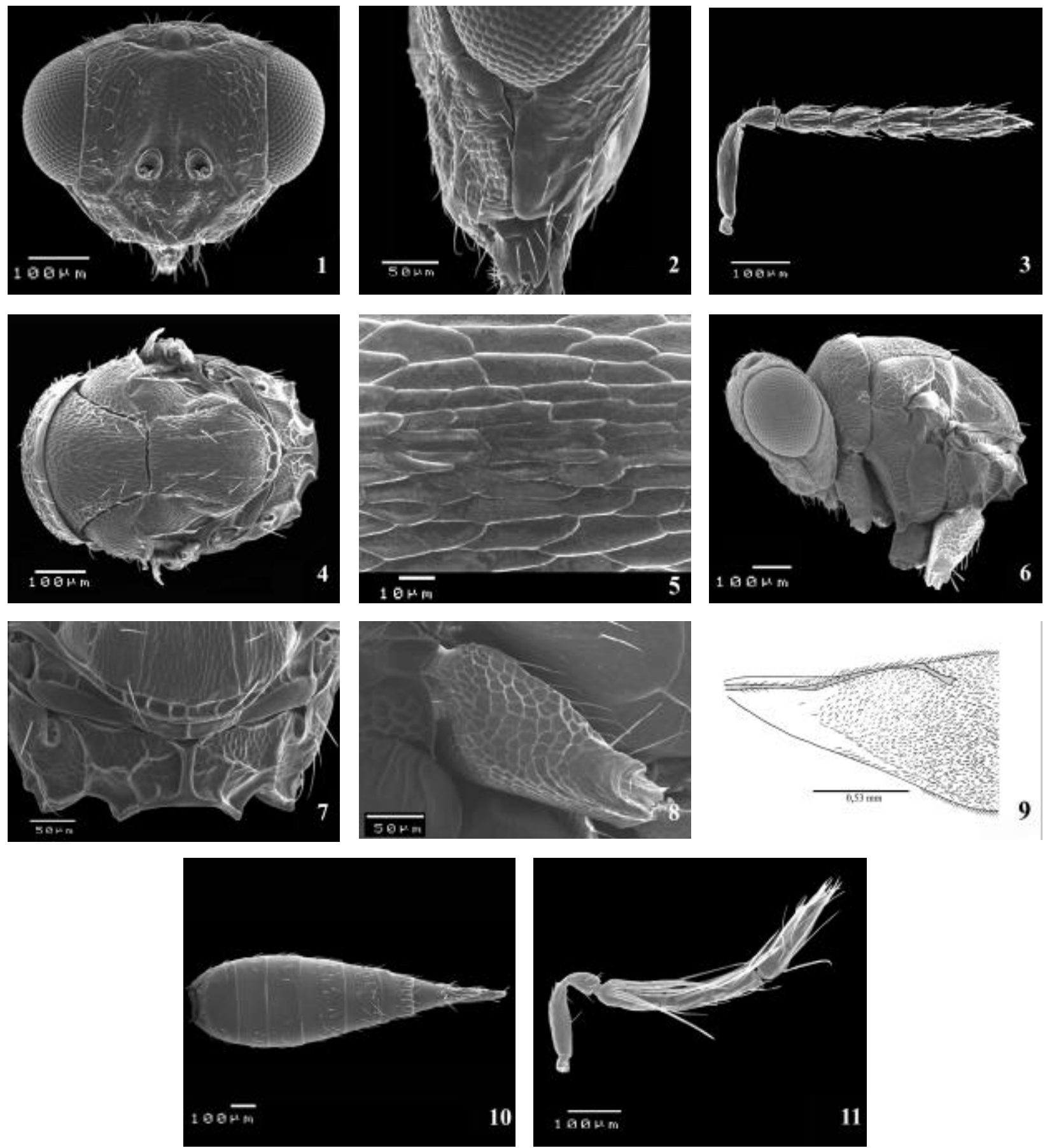

Figs. 1 to 11 -G. itaunasp.nov.1-10 female.1. Head, frontal view;2. Head, lateral view, detail of the malar space; 3. Antenna; 4. Mesosoma, dorsal view; 5 . Scutellum, detail of the sculpturing; 6 . Head and mesosoma, lateral view; 7 . Propodeum; 8. Metacoxa; 9. Fore wing, 10. Metasoma, dorsal view. 11. Antenna, male.

Fore wing: $2.1 \times$ longer than wide; submarginal vein 2.6x length of marginal vein; marginal vein $2.1 \times$ length of stigmal vein and $1.1 \times$ length of postmarginal vein.

Metasoma (Fig. 18): petiole 3.7 $x$ longer than wide; compressed in lateral view, $2.2 \times$ longer than wideand $1.4 \times$ longer than high; Mt4, in lateral view, the larger.

Female variation: body length $2.6-2.7 \mathrm{~mm}$. The color of mesopleuron, scutellum, axillae and propodeum can be lighter; POL/OOL 1.6-1.7; antenna: scape 4.0-4.9 x, pedicel 1.4-1.6x, F1 (1.6-1.9x), F2 (1.6-1.8x), F3 (1.5-1.6x), F4 (1.4-1.5x), F5 (1.3-1.5x) and clava3.4-3.8x longer than wide. Mesosoma 1.7-2.1 $x$ longer than wide in dorsal view.Forewing 2.1-2.2xlongerthan wide; submarginal vein 2.1-2.6x length of marginal vein; marginal vein 2.1$2.4 \times$ length of stigmal vein and 1.1-1.4 $\times$ length of post marginal vein. Petiole 3.5-4.0 $\times$ longer than wide. Metasoma 1.3-1.4 $\times$ longer than high in lateral view and 1.7-2.2 $x$ longer than wide in dorsal view. 

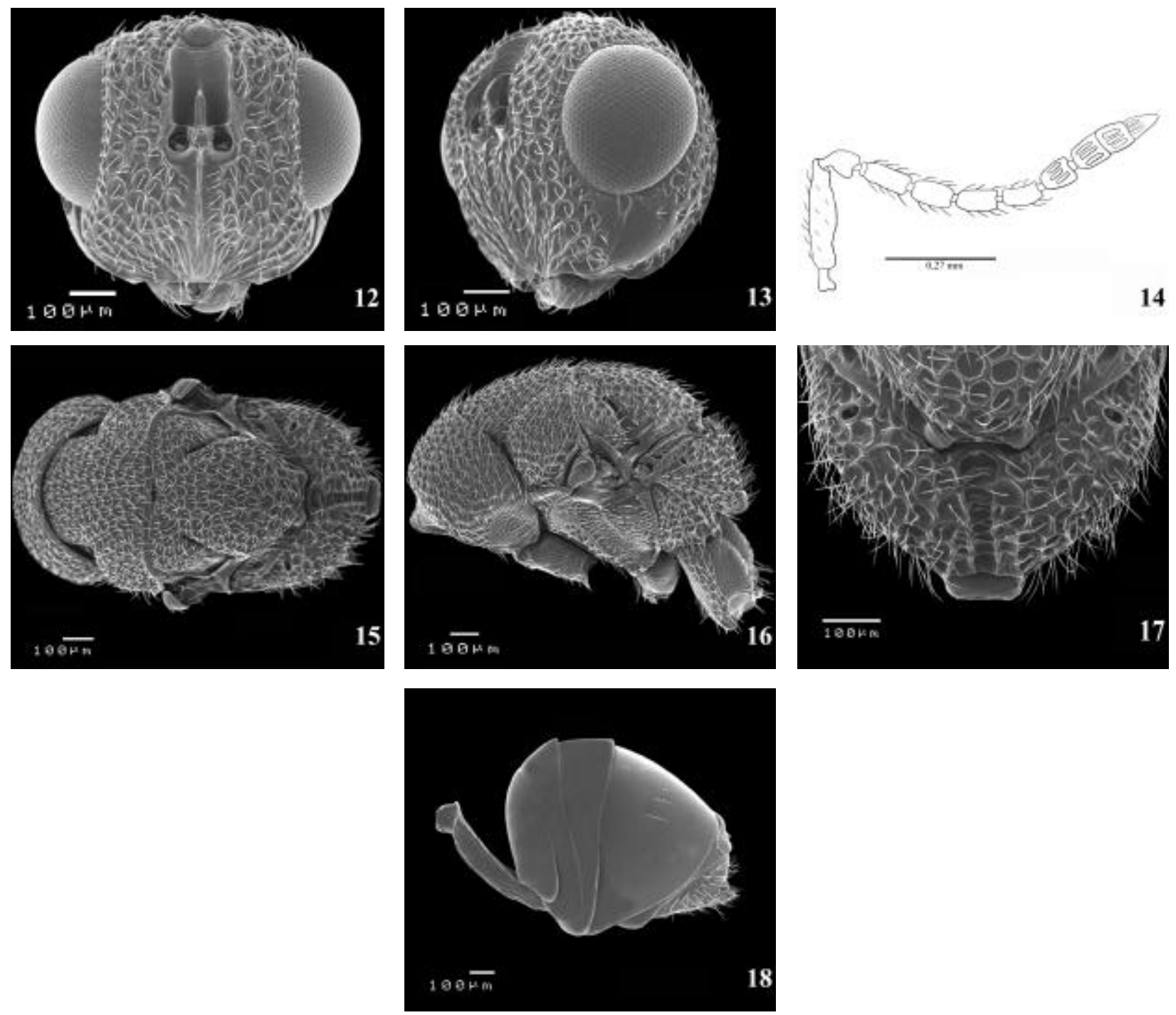

Figs. 12 to 18 - P. juliae sp. nov. female. 12. Head, frontal view; 13. Head, lateral view; 14. Antenna; 15. Mesosoma, dorsal view; 16. Mesosoma, lateral view; 17. Propodeum; 18. Metasoma, lateral view.

Male: unknown.

Distribution: Descalvado, São Paulo State, Brazil.

Remarks: Prodecatoma juliae sp. n. is most similar to P. spermophaga Costa Lima, 1928 in morphology and coloration of the body; unlike $P$. spermophaga they show larger body size, presence of post orbital carina, ticker genal carina sculptured that do not reach this margin and propodeum medially glabrous delimited by plical carina, without costula and median carina.

Biology: Prodecatoma juliae sp. n. were reared from seeds of Ilex affinis (Aquifoliaceae). Aquifoliaceae is a new family of host plant for Prodecatoma.

Etymology: The specific epithet honors Júlia Navarro Perioto, daughter of the first author.

Type material (18females): Holo type female(MZSP):

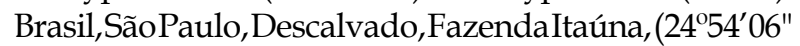
S/ 47³7'26" O), 24.II.2006. N.W. Perioto e eq. col., ex. frutos de Ilex affinis (Aquifoliaceae). Paratypes: same data as holotype; 10 females (MZSP), 7 females (UFES).

\section{ACKNOWLEDGEMENTS}

We thank the Departamento de Biologia Celulare Molecular e Bioagentes Patogênicos da Faculdade de Medicina de Ribeirão Preto/USP by the permission of use of the SEM, José Augusto Maulim and Maria Dolores Seabra Ferreira for helping to take the scanning electron micrographs and the anonymous reviewers for corrections and suggestions.

\section{REFERENCES}

DALMOLIN, A.; MELO, G.A.R.; PERIOTO, N.W. Novas espécies de Prodecatoma (Hymenoptera, Eurytomidae) associadas a galhas de duas espécies de Psidium L. (Myrtaceae), com comentários sobre Prodecatoma spermophaga. Revista Brasileira de Entomologia, v.48, n.4, p.519-528, 2004. 
DURIGAN, G.; BAITELO, J.B.; FRANCO, G.A.D.C.; SIQUEIRA, M.F. Plantas do cerrado paulista: imagens de uma paisagem ameaçada. São Paulo: Páginas \& Letras Editora e Gráfica, 2004. p.46.

GIBSON, G.A.P. Morphology and terminology. In: GIBSON, G.A.P., HUBER, J.T.; WOOLEY, J.B. (Ed.). Annotated keys to genera of Neartic Chalcidoidea (Hymenoptera). Ottawa: NRC Research Press, 1997. p.16-44.

GIRAULT, A.A. New syrphidoid, cynipoid and chalcidoid Hymenoptera. Proceedings of the United States National Museum, v.58, p.177-216, 1920.

HARRIS, R.A. A glossary of surface sculpturing. Occasional Papers in Entomology, v.28, p.1-31, 1979.

LASALLE, J.; PEÑA, J.E. A new species of Galeopsomyia (Hymenoptera: Eulophidae: Tetrastichinae): a fortuitus parasitoid of the citrus leafminer, Phillocnistis citrella (Lepidoptera: Gracilariidae). Florida Entomologist, v.80, n.4, p.461-470, 1997.

MANEN, J.F.; BOULTER M.C.; NACIRI-GRAVEN, Y. The complex history of the genus Ilex $\mathrm{L}$. (Aquifoliaceae): evidence from the comparison of plastid and nuclear DNA sequences and from fossil data. Plant Systematics and Evolution, v.235, p.79-98, 2002.

NOYES, J.S. Universal Chalcidoidea Database. The Natural History Museum, London, 2003. Disponível em: <http://www.nhm.ac.uk/research-curation/ projects/chalcidoids/>. Acesso em: 21 ago. 2006.

PERIOTO, N.W.; LARA, R.I.R. Revisão da bibliografia do gênero Prodecatoma Ashmead, 1904 (Hymenoptera, Chalcidoidea, Eurytomidae). Arquivos do Instituto Biológico, São Paulo, v.71, n.1, p.133-135, 2004.

PERIOTO, N.W.; COSTA, V.A.; LARA, R.I.R. Two new species of Galeopsomyia (Hymenoptera, Eulophidae) from Brazil. Revista de Agricultura, v.82, n.3, p.291-297, 2007.

SCHAUFF, M.E.; LASALLE, J.; COOTE, L.D. Eulophidae. In: GIBSON, G.A.P., HUBER, J.T.; WOOLEY, J.B. (Ed.).

Annotated keys to genera of Neartic Chalcidoidea (Hymenoptera). Ottawa: NRC Research Press, 1997. p.327-429.

Received on 6/2/07

Accepted on 24/11/08 